\title{
THE EFFECT OF CLIMATE CHANGE ON THE PHENOLOGY OF MOTH ABUNDANCE AND DIVERSITY
}

\author{
GIMESI, L. ${ }^{1}-$ HOMORÓDI, R. ${ }^{2}-$ HIRKA, A. ${ }^{3}-$ SZABÓKI, Cs. ${ }^{3}-$ HUfNAGEL, L. ${ }^{4} *$ \\ ${ }^{1}$ University of Pécs, Faculty of Natural Sciences, Department of Informatics, \\ 7624 Pécs, Ifjúság út 6., Hungary \\ ${ }^{2}$ ALÖKI Applied Ecological Research and Forensic Institute Ltd. \\ 1185 Budapest, Kassa utca 118., Hungary \\ ${ }^{3}$ Forest Research Institute, Department of Forest Protection \\ 3232 Mátrafüred, Hegyalja út 18., Hungary \\ 4 “Adaptation to Climate Change” Research Group, Hungarian Academy of Sciences \\ 1118 Budapest, Villányi út 29-43., Hungary \\ *Corresponding author \\ e-mail: leventehufnagel@gmail.com \\ (Received $10^{\text {th }}$ March 2012; accepted 27 ${ }^{\text {th }}$ March 2012)
}

\begin{abstract}
When examining the ecological effects of climate change those databases which contain monitoring results of long-term time series have a key role. We used the daily Lepidoptera data of the Hungarian Plant Protection and Forestry Light Trap Network between 1962 and 2006 to analyse the influence of the change of temperature on the ecological dynamics of Lepidoptera. Using the quantile regression analyses we concluded that in the examined period, for the total number of individuals, seasonal phenomena shifted forward, however the days with higher diversity occurred over a shorter period. The analysis of the heat sums shows that the spring warming started earlier, although, at the same time the low quantiles of the captured Lepidoptera occurred at lower and lower heat sums over the years, while the heat sums at which the high quantiles of the number of Lepidoptera occurred showed a steady increase, meaning that the active period of the Lepidoptera community has expanded. A strong correlation was observed between diversity and temperature.
\end{abstract}

Keywords: biodiversity, quantile regression, climate change, Lepidoptera, light trap

\section{Introduction}

Since the last decades the effects of climate change on the dynamical behaviour and the size of Lepidoptera populations have become more and more obvious. Seasonal community dynamics (ecological processes) are, out of the meteorological parameters, primarily influenced by temperature.

Our objective was to examine the effects of temperature change on community dynamics. We chose the light-attracted species assembly of Lepidoptera, which is an adequate indicator of the above ecological phenomena (Hufnagel et al., 2008).

The data was collected from the database of the Hungarian Plant Protection and Forestry Light Trap Network. The description of the database is presented by Gimesi and Hufnagel (2010). This choice had been motivated by the national coverage of the light trap network, the large number of captured Lepidoptera individuals, and also by the availability of a long-term data series (between 1962 and 2006).

Various methods exist that demonstrate changes in a community: different diversity indices, gradations, species abundance models, quantile regression. We chose quantile 
regression for our study, which is ideal for examining population dynamics and demonstrating changes (Cade et al., 2005; Helmus et al., 2007). Linear regression demonstrates the ratio of occuring changes in a simple way (Chamaillé-Jammes et al., 2007). With the help of this method we observed that both heat sum and the appearance of species shifted earlier and earlier over the years.

Many authors agree on the seasonal dependence of community dynamics, regardless of the climate (temperate or tropical) of the area where the research was carried out. Szabó et al. (2007) used the number of species and the number of individuals for the demonstration of seasonal changes, while Fisher at al. (1943) used a diversity index. Species abundance models are also suitable for the examination of seasonal dynamics. With the help of the above methods different periods can be well separated.

We used the traditional two-dimensional time series figures for the presentation of seasonal changes, in which the seasonal dependence of population dynamics can be seen clearly.

\section{Review of literature}

The most common method of collecting night-flying insects is light trapping. This method has been applied since Williams' experiments (1935). In Hungary light traps have been used since 1940; in 1952 the construction of a worldwide unique trap network began (Jermy, 1961; Nowinszky, 2003a). Today, the Hungarian light trap network is equipped uniformly with Jermy-type light traps.

In order to discover the occurring changes and their tendencies in a data series, a long time series (daily data series) is needed, with great geographical coverage, and data collection needs to be done with the same method along the way, in every location. The data series of the Hungarian Plant Protection and Forestry Light Trap Network meets these requirements (Hufnagel et al., 2008).

For the investigation of population dynamics those light traps are best suited which have been operating for the longest time without interruption, in the same place (Nowinszky, 2003b). Also because of the effects of different abiotic factors, the largest possible number of light trap data coming from different locations should be used. This ensures that the effects occurring at different capturing sites, and modifying the number of captures, compensate each other (Nowinszky, 2003b). A large quantity of data, coming from various sources, can be processed with data mining methods. In our case the detailed description of the database has been reviewed by Gimesi and Hufnagel (2010).

The number of Lepidoptera captured significantly depends on several biotic and abiotic environmental factors. Naturally, the different environmental effects do not appear independently from each other, but mostly in interaction (Nowinsky, 2003b). A major part of the literature (Nowinszky, 1977; Persson, 1976; Rácz and Bernáth, 1993; Williams, 1962) primarily studies the elements of weather and their combined effects.

In Hungary the correlations between the number of captured individuals and weather elements have been investigated since the end of 1950s. Nowinsky et al. (2003) came to the conclusion, based on the works of several authors, that temperature had a fundamental role in flying activity, which derives from the physiological features of Lepidoptera. This assumption is supported by Kádár and Erdélyi (1991), as well as by Schmera (2002), among others. 
Nowadays several diversity indices are used for the characterization of diversity. Among these Shannon-entropy is used the most frequently (Juhász-Nagy, 1993). A major part of the literature (e.g. Acara et al., 2007; Arnan et al., 2009; Balog et al., 2008; Chefaoui and Lobo, 2008; Kevan, 1999; Skalskia and Pośpiech, 2006; Suzuki et al., 2002) applies primarily this index.

Besides species diversity investigations, species abundance models have also been worked out (Izsák and Szeidl, 2009). They examine the number of individuals (abundance) within different species that are part of the studied community (Magurran, 1988; Bartha et al., 2007).

Besides these two approaches, quantile regression is also used, which is an effective tool for the demonstration of changes (Cade at al., 2005; Helmus, et al., 2007). Linear regression demonstrates the ratio of occuring changes in a simple way (ChamailléJammes et al., 2007). With the help of quantile regression such correlations can be discovered, that cannot be with traditional statistical methods.

In case of quantile regression the changes of a given proportion of the measurement data are demonstrated. Similar analyses were carried out by Austin (2007), Anderson (2008) and Cade and Noon (2003), as well as Koenker and Hallock (2001). Kovács et al. (2009) used linear quantile regression for the demonstration of population dynamics.

Williams and Liebhold (2002) drew attention to the fact that insects were affected by even a relatively small climate change. Williams (1940) investigated the long-range effects of weather on population changes, and its short-range effects on the activity.

With the increase of temperature due to climate change, the living areas of species get shifted north (Virtanen and Neuvonen, 1999). Continental species are shifted towards the poles by an average of 6.1 kilometers every 10 years, or every 6 meters higher in the mountains (Parmesan and Yohe, 2003).

Environmental effects do not only influence the given year, but also affect the future development of populations, as it is referred to by Hufnagel et al. (2008). Therefore, besides seasonal change, numerous publications deal with long-term tendencies and the effects of climate change. According to Tobin et al. (2008) the number of pest insects increases with the rise of temperature, which can have significant ecological and economic consequences.

Wolda et al. (1998) described the yearly seasonal changes of Lepidoptera captured with light traps at different geographical locations, and studied the connection between these and different meteorological parameters. They found that most species were characterized by seasonality, even in tropical environment, which showed similar patterns in consecutive years. This phenomena is also supported by Caldas (1992), who, based on a 1-year data series, explained seasonal dependence with the change in precipitation, although he has not investigated temperature.

In Japan, Kimura et al. (2008), examining Trichoptera species, found seasonal dependence as well as a significant correlation between abundance and temperature in spite of the fact that the abundance maximum of the insects they observed occured in September, while the temperature maximum were in August.

Schmera (2002) examined Trichoptera captured with light traps from May to October. To present seasonal dependence he used the species gradation figure, the Rényi-type diversity index and the right tail sum, and found that no significant difference could be seen in the data figures between May and September, however October was significantly different from the other months. 
Researches by Szabó et al. (2007) on the fauna change of Macroheterocera captured over an 8-year period showed the seasonal dependence of the number of species and individuals. According to it, a smaller peak was reached at the end of March and in the beginning of September, while in late May and early July there were higher ones. At the end of June there was a decline.

In England, Fisher et al. (1943) studied a 4- year time series of Macrolepidoptera captured with light traps, from April to October, and depicted seasonal changes on a graph indicating the number of species and individuals as well as Fisher's alpha value.

\section{Material and method}

In the course of our work the database of the Hungarian Plant Protection and Forestry Light Trap Network was used, whose first light traps were installed in 1961 (Szontagh, 1975). These traps are operating all year round, except for those days when the temperature does not rise above $0{ }^{\circ} \mathrm{C}$, or when the area is covered with snow (Nowinszky, 2003a).

The collection data of the Hungarian Plant Protection and Forestry Light Trap Network were analysed with data-mining methods.

Due to the effects of various abiotic factors it seemed reasonable to work with the maximum number of data, so that the effects occurring at different capturing sites, modifying the number of captures, could compensate each other (Nowinszky, 2003b). To produce a national time series the trap data found at different locations needed to be merged for each species. After the work of Moon and Kim (2007) this process is called data reduction.

To filter out extremes occurring in the databases and in order to reduce fluctuations in the data series the moving average method was used. When calculating the movingaverage we considered the 4-4 adjacent daily data as well, that is the average of 9 days ( $9^{\text {th }}$ grade moving average). Number 9 was chosen, because it equals to the number of traps. After calculating the average, a 16425-line database was created containing the daily data series of 281 Lepidoptera species captured between 1962 and 2006.

To create the insect data warehouse, for data filtering, and for further data processing a Visual Basic software was created. Using this programming language Excel and Access files could be managed directly.

As meteorological data source the "kutdiak" database (Ferenczy, 2008) and the "KKT" database (Szenteleki, 2007; Szenteleki et al., 2007) were used. The second one, in addition to meteorological data, contains the geographical coordinates of Hungarian cities. For the filtering and checking of the databases, data published on the website of the National Meteorological Service (2008) were used.

In Hungary, the connections between captured individuals and the elements of weather have been investigated since the late 1950s. In the literature it is a generally accepted fact that flying activity, and so the number of captures is primarily influenced by temperature. Precipitation, wind and other environmental effects influence it only to a small extent and only locally.

To study community changes, the method of linear quantile regression was used and for our analyses the GRETL (GNU Regression, Econometric and Time-series Library) (Cottrell and Lucchetti, 2009) and Microsoft Excel programs were used. 


\section{Results}

One of the methods to investigate community changes is the calculation of linear quantile regression, where the changes of a given ratio $(10,20,30,40,50,60,70,80$, $90 \%$ ) of the measurement data are characterized by a linear quantile regression.

\section{Examination of the number of captured individuals}

The days of the year, on which the number of captured individuals reached 10 , $20 \ldots 90 \%$ of the annual sum were investigated.

Due to the fact that in the years 1972 and 1973 trapping and filling the database were uncertain, we studied the periods between 1962 and 2006 (Fig. 1), and 1974 and 2006 (Fig. 2) separately.

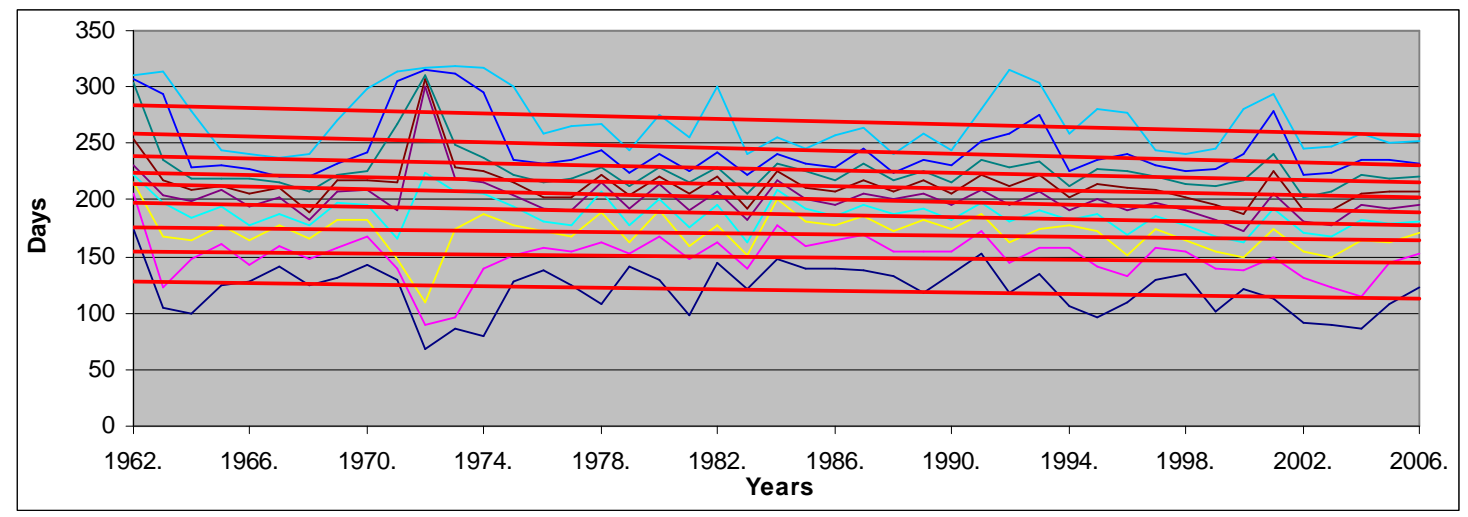

Figure 1. The linear quantile regressions of the number of individuals between 1962 and 2006

Table 1. Analyses of the regression lines

\begin{tabular}{c|c|c}
\hline Quotient & Coefficient & Standard error \\
\hline $10 \%$ & -0.349 & 0.245 \\
$20 \%$ & -0.215 & 0.227 \\
$30 \%$ & -0.268 & 0.190 \\
$40 \%$ & -0.476 & 0.150 \\
$50 \%$ & -0.557 & 0.208 \\
$60 \%$ & -0.486 & 0.206 \\
$70 \%$ & -0.544 & 0.229 \\
$80 \%$ & -0.622 & 0.298 \\
$90 \%$ & -0.594 & 0.296 \\
\hline
\end{tabular}

The regression coefficient of all regression lines are negative, which shows that the captures were getting earlier.

$10 \%$ of the annual sum of the number of individuals was reached 15 days earlier in 2006 than in 1962, while $90 \%$ of it was reached 26 days earlier. The ratios shifted 20 days earlier on average. 


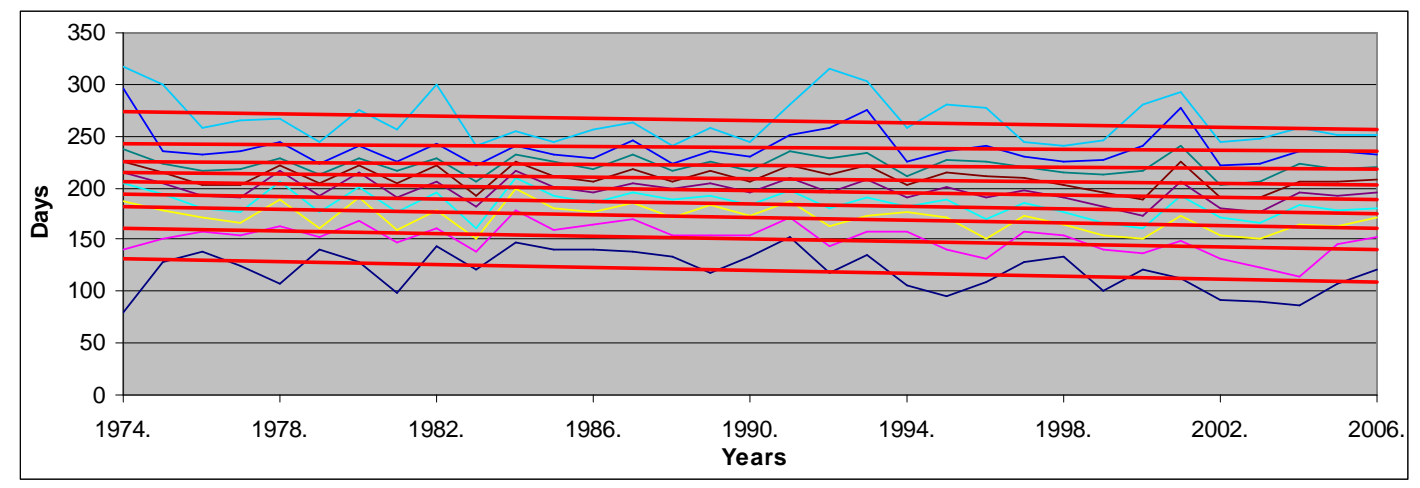

Figure 2. The linear quantile regressions of the number of individuals between 1974 and 2006

Table 2. Analyses of the regression lines

\begin{tabular}{c|c|c}
\hline Quotient & Coefficient & Standard error \\
\hline $10 \%$ & -0.658 & 0.337 \\
$20 \%$ & -0.691 & 0.227 \\
$30 \%$ & -0.627 & 0.213 \\
$40 \%$ & -0.580 & 0.206 \\
$50 \%$ & -0.516 & 0.187 \\
$60 \%$ & -0.391 & 0.186 \\
$70 \%$ & -0.194 & 0.170 \\
$80 \%$ & -0.223 & 0.310 \\
$90 \%$ & -0.540 & 0.407 \\
\hline
\end{tabular}

Negative steepness (coefficient) of the regression lines was observed here as well. $10 \%$ of the annual sum of the number of individuals was reached 21 days earlier in 2006 than in 1974, while $90 \%$ of it was reached 18 days earlier. The ratios shifted 16 days earlier on average.

\section{Investigation of the heat sum}

The heat sum was investigated as a phenological indicator. The days of the year, on which the heat sum reached $10,20 \ldots 90 \%$ of the annual sum of daily mean temperatures (annual heat sum) were analysed.

As the minimum temperature in the examined period was $-12.6^{\circ} \mathrm{C}$ data needed to be transformed, when calculating the heat sum, in a way that $13^{\circ} \mathrm{C}$ was added to each temperature value. This way we could avoid counting with negative values. The quantile regression lines received after the calculation is shown in Figure 3.

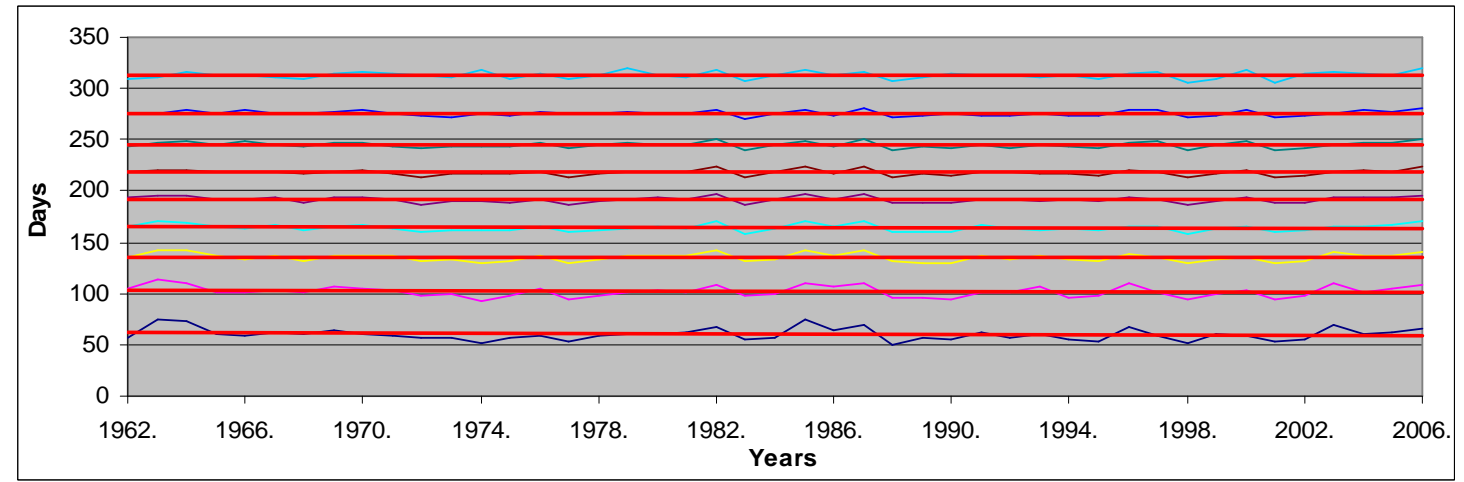

Figure 3. The linear quantile regressions of the heat sum between 1962 and 2006 
Table 3. Analyses of the regression lines:

\begin{tabular}{c|c|c}
\hline Quotient & Coefficient & Standard error \\
\hline $10 \%$ & -0.059 & 0.068 \\
$20 \%$ & -0.046 & 0.060 \\
$30 \%$ & -0.031 & 0.045 \\
$40 \%$ & -0.024 & 0.039 \\
$50 \%$ & -0.013 & 0.033 \\
$60 \%$ & 0.002 & 0.030 \\
$70 \%$ & -0.014 & 0.033 \\
$80 \%$ & -0.006 & 0.031 \\
$90 \%$ & 0.009 & 0.039 \\
\hline
\end{tabular}

At the lower percentages of heat sum a negative steepness was observed, meaning that it started getting warm earlier. In case of the higher percentages the steepness is or is around zero (sometimes positive, sometimes negative). The above different tendencies of the regression lines indicate that the warm period was extending while the cold (winter) one was getting shorter.

$10 \%$ of the annual heat sum was reached 2.5 days earlier in 2006 than in 1962, while $90 \%$ of it was reached on the same day.

\section{Connection between heat sum and the number of captured individuals}

That heat sum was investigated, at which the number of captured individuals reached $1,2 \ldots 10 \%$ of the total annual captures (Fig. 4), as well as 10, 20...90\% of it (Fig. 5).

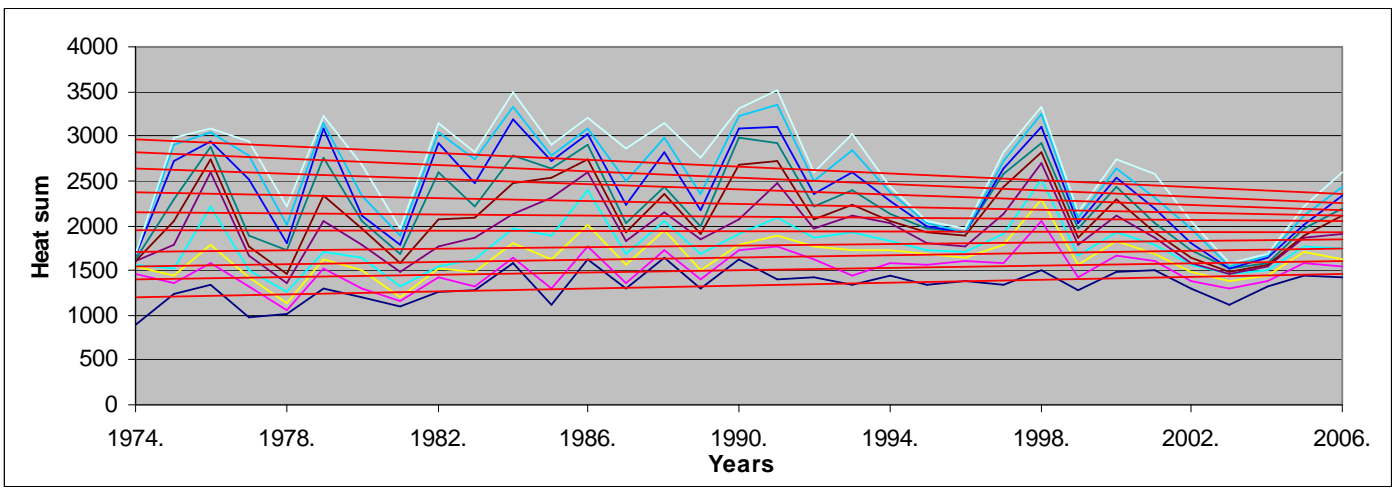

Figure 4. The 1, 2...10\% linear quantile regressions of heat sum-number of captured individuals between 1974 and 2006

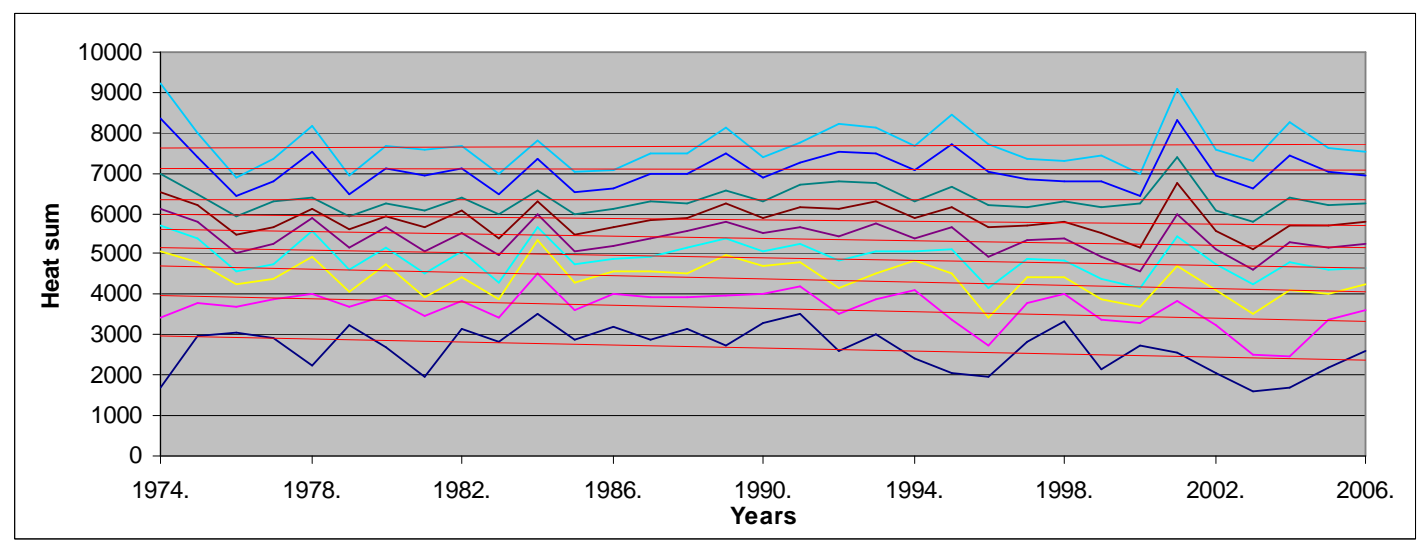

Figure 5. The 10, 20...90\% linear quantile regressions of heat sum-number of captured individuals between 1974 and 2006 
Table 4. Analyses of the regression lines:

\begin{tabular}{c|c|c|c|c|c}
\hline Quotient & Coefficient & Standard error & Quotient & Coefficient & Standard error \\
\hline $1 \%$ & 8.272 & 3.054 & $10 \%$ & -18.875 & 9.538 \\
$2 \%$ & 6.440 & 3.521 & $20 \%$ & -20.878 & 7.588 \\
$3 \%$ & 6.147 & 4.085 & $30 \%$ & -18.993 & 7.477 \\
$4 \%$ & 4.286 & 5.099 & $40 \%$ & -16.287 & 7.180 \\
$5 \%$ & -0.552 & 6.162 & $50 \%$ & -13.623 & 6.653 \\
$6 \%$ & -3.372 & 7.239 & $60 \%$ & -8.013 & 6.686 \\
$7 \%$ & -8.401 & 8.072 & $70 \%$ & 0.497 & 6.143 \\
$8 \%$ & -14.992 & 8.848 & $80 \%$ & -0.993 & 8.934 \\
$9 \%$ & -17.744 & 9.195 & $90 \%$ & 2.193 & 10.329 \\
\hline
\end{tabular}

In the analyses it is seen that for the appearance of Lepidoptera, under the $4 \%$ quantile greater and greater heat sum was needed over the years (see the 4 lowest lines in Fig.4). However, for further captures less and less heat sum was required (Fig.5).

\section{Investigation of a diversity index}

The days on which the Shannon-diversity index reached $10,20 \ldots 90 \%$ of the maximum value in the given year (between 1974 and 2006) were examined (Fig. 6).

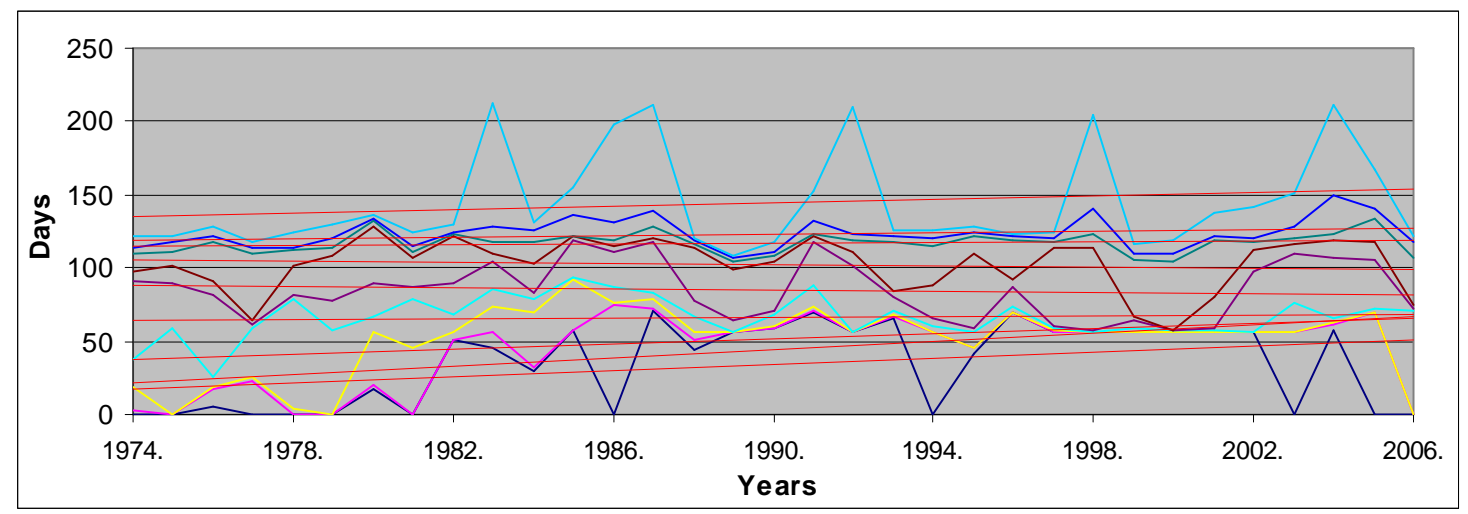

Figure 6. The 10,20...90\% linear quantile regressions of the diversity index between 1974 and 2006

Table 5. Analyses of the regression lines

\begin{tabular}{c|c|c}
\hline Quotient & Coefficient & Standard error \\
\hline $10 \%$ & 1.068 & 0.481 \\
$20 \%$ & 1.447 & 0.384 \\
$30 \%$ & 0.884 & 0.421 \\
$40 \%$ & 0.110 & 0.266 \\
$50 \%$ & -0.233 & 0.361 \\
$60 \%$ & -0.227 & 0.333 \\
$70 \%$ & 0.090 & 0.137 \\
$80 \%$ & 0.240 & 0.184 \\
$90 \%$ & 0.594 & 0.605 \\
\hline
\end{tabular}

Diversity index increased until the 50 and $60 \%$ quantiles, where the steepness became negative indicating a decrease in the diversity index. After this an ascending tendency can be seen again. 


\section{Seasonal dependence}

The averages of daily mean temperatures, diversity indices, the numbers of individuals and species concerning the same days of the years within the period between 1974 and 2006 are shown in Figure 7. It presents how different values changed as a function of the day of the year (for the sake of better visualisation, values were weighted to obtain similar scaling).

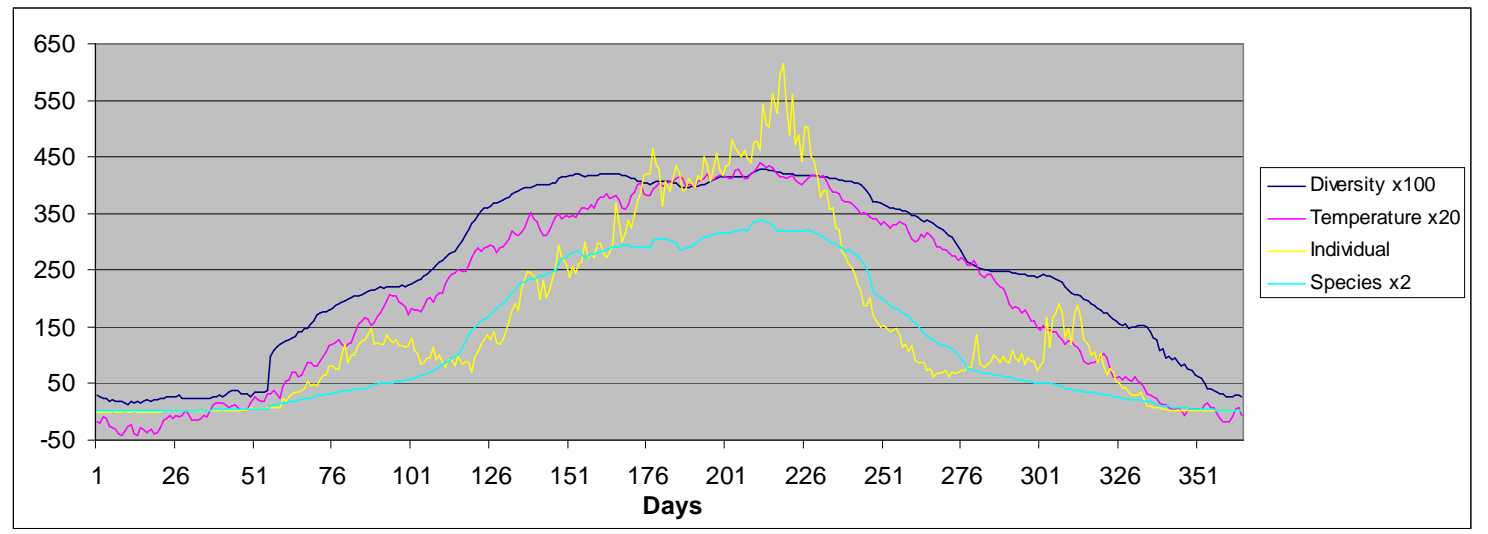

Figure 7. The averages of temperatures, diversity indices, the numbers of individuals and species concerning the same days of the years within the period between 1974 and 2006

Although temperature increased till the end of February as it is shown in Figure 7, diversity index was low and relatively constant during the winter period. After that (at spring) it started increasing significantly and stayed relatively constant during the summer, apart from a decline in the middle of summer. After September the diversity index started decreasing.

According to Fig.7 there were two smaller peaks in the number of individuals in the early spring and late autumn, besides the regular summer maximum. These two rises were caused by species appearing only in these periods. The number of individuals reached its maximum when the temperature had already begun to decline.

The graph of the number of species begins to rise more significantly towards the end of spring. It reaches its maximum in the second half of July, after a small increase, where it begins to decline sharply. The maximums of the number of species and the temperature approximately coincided.

Figure 8 shows the values of daily mean temperature of 33 years as a function of the days of the year, and Figure 9 shows diversity values in the same way. 


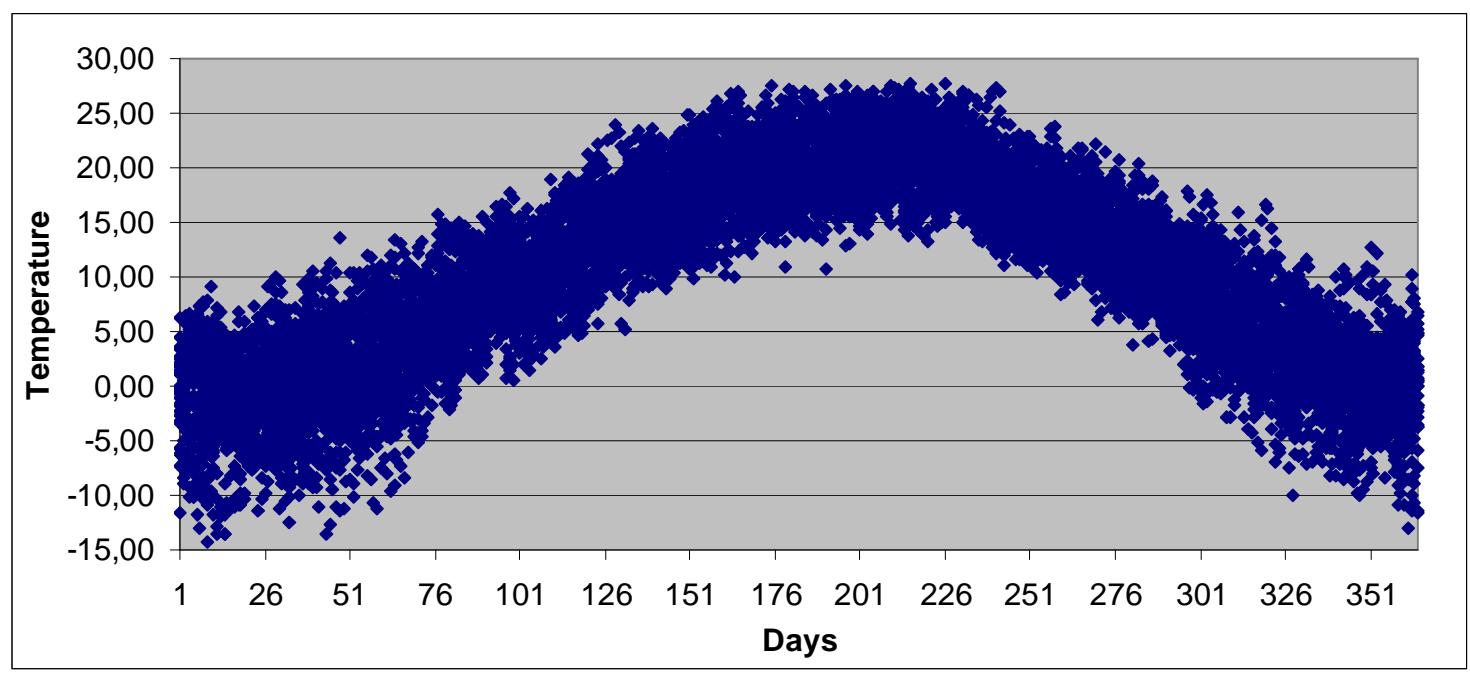

Figure 8. Daily mean temperatures in the years between 1974 and 2006

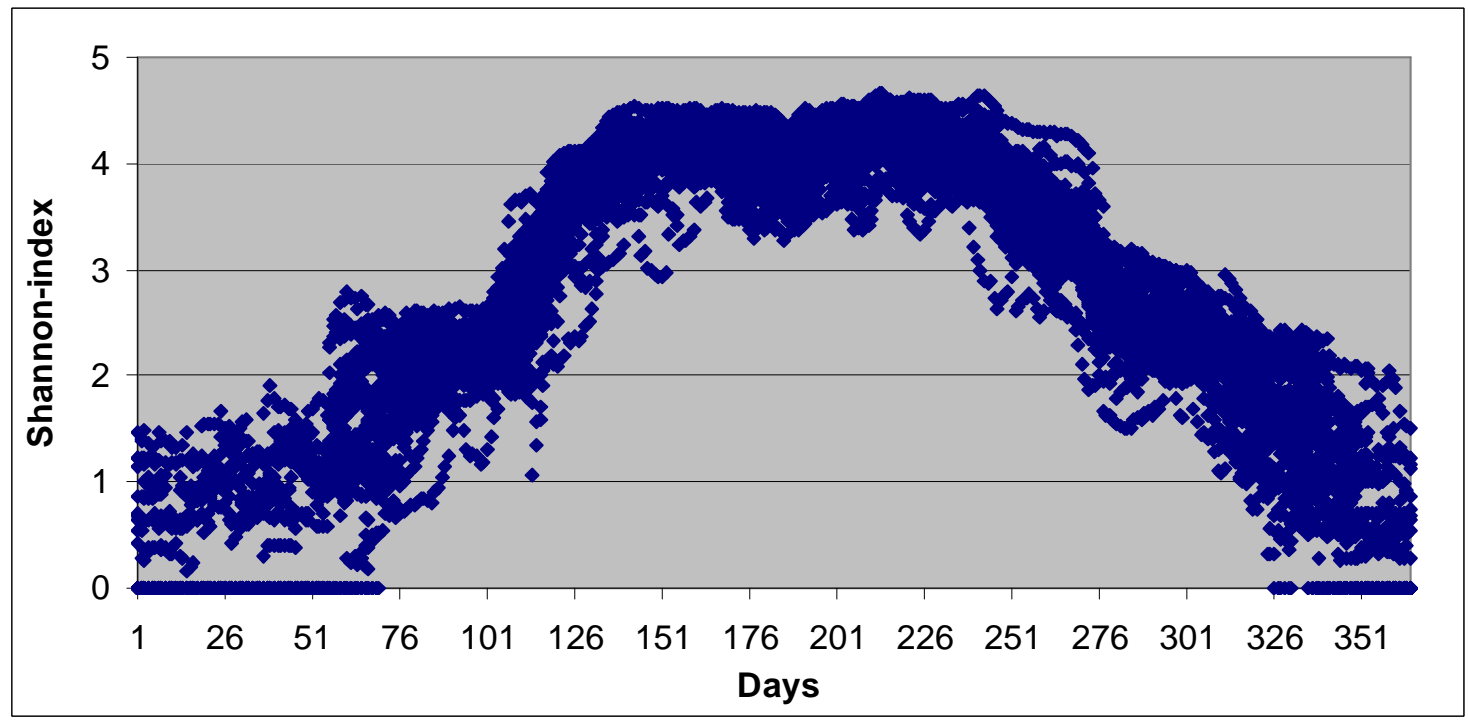

Figure 9. Daily diversity indices in the years between 1974 and 2006

It can be seen that when the standard deviation of temperature is greater (at winter, early spring and late fall), the standard deviation of the diversity index is more significant as well. The correlation between these two values is 0.6953 . Figure 10 shows the standard deviations of the temperature and of the diversity index.

It can be seen in Figure 9 that there were days in January, February and December, when the diversity index was zero, which means that there were no captures on those days. This cannot be observed on the other days of the year.

Furthermore, it can also be seen that the value of diversity was smaller at a lower temperature, and greater when the temperature was higher, although diversity only rised with temperature until a certain point. At the beginning of July even a decline was observed. 


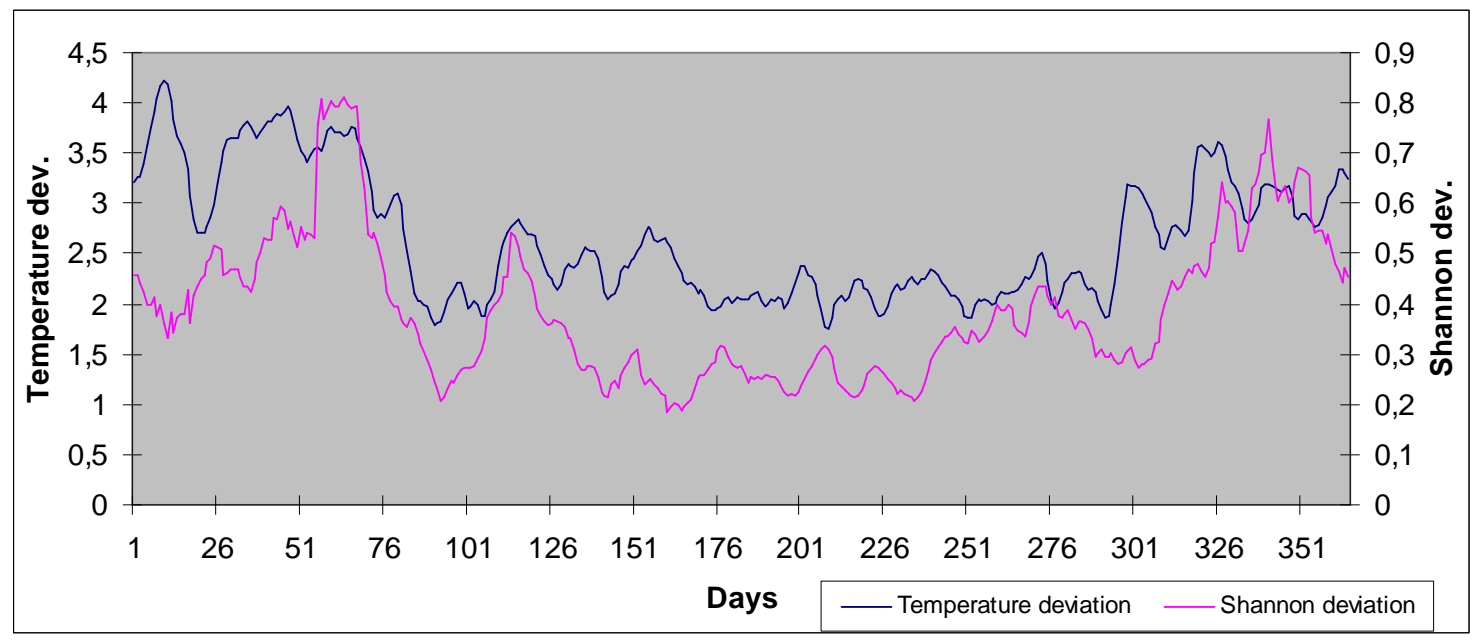

Figure 10. The standard deviations of temperature and diversity index in the years between 1974 and 2006

Figure 11 shows the connection between temperature and diversity. It is obvious that there is a significant $(0.9815)$ correlation between them.

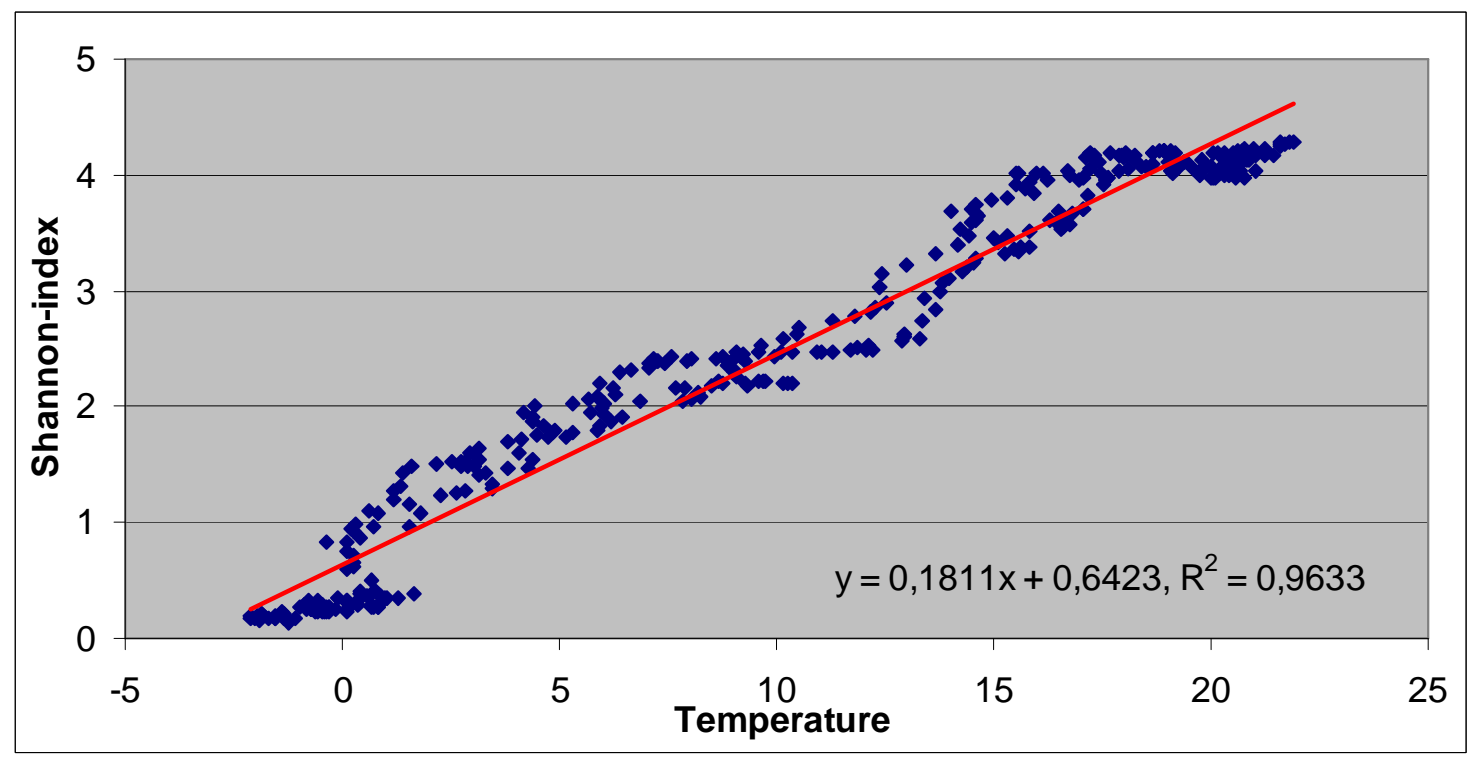

Figure 11. The change of diversity index as a function of temperature calculated with the averages of the years between 1974 and 2006

Examining the standard deviation of temperature and the diversity index on Figure 12 , it can be seen that as the standard deviation of temperature increased, the diversity index decreased. These two values are negatively correlated (-0.7949). 


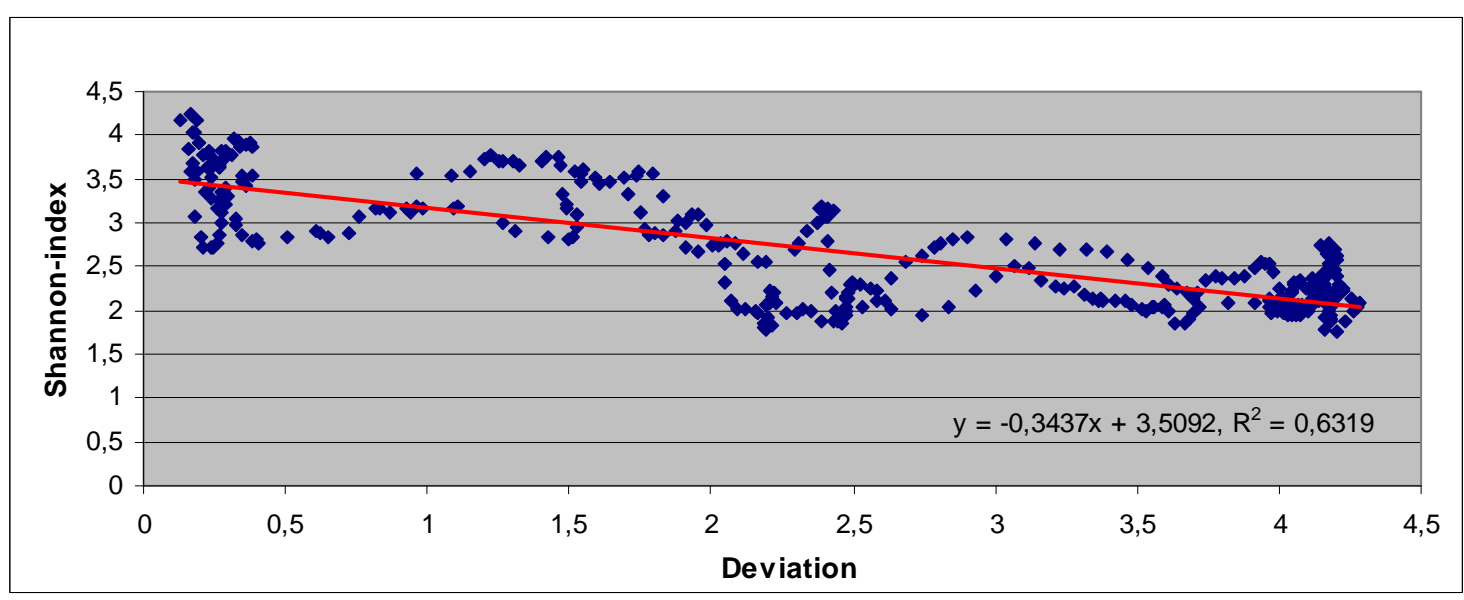

Figure 12. Change of diversity index as a function of the standard deviation of temperature calculated with the averages of the years between 1974 and 2006

\section{Discussion}

The database compiled by us from the data of the Hungarian Plant Protection and Forestry Light Trap Network is suitable for application in important research areas of the national light trapping summarized by Szentkirályi (2002), for fauna, zoogeographical, taxonomic, zoocoenological, ethological, phenological, ecological, etc. examinations (Nowinszky, 2003b).

In our present study the long-term seasonal changes of the data were examined. Investigating the change in the number of individuals we found that the appearance of species is approximately 2-3 weeks earlier than 30 years ago. Similar changes were observed by Kovács et al. (2009), who, examining the migration of birds, experienced an almost one week shift earlier over 24 years.

No significant changes happened during the investigated period of the exceeding days of the $10,20 \ldots 90 \%$ of the annual heat sum, however it was found that the exceeding days of the lower percentages had negative tendency, while the exceeding days of higher percentages had a tendency around zero, which altogether refers to the extension of the growing season. This is consistent with the forward shift of the seasonal pattern of the total number of Lepidoptera individuals.

However, our analyses of the diversity indices showed that the increase of the different diversity index values shifted forward.

Examining the correlation between the capturing data of Lepidoptera and the daily mean temperatures we found that the values of daily mean temperature and the daily diversity closely correlated (Fig. 11), which corresponds to what Ferenczy et al. (2010) observed. However, diversity and the standard deviation of temperature showed negative correlation (Fig. 12).

Some authors reported an increase (e.g. Bazzaz, 1975), while others a decrease in the number of individuals (e.g. Nowinszky et al., 2003) as a function of temperature. Taylor, (1963) found that flying and, as a consequence, capturing had both lower and upper temperature threshold values. This statement was supported by our investigations (Fig. 8), i.e. that in the warmest summer period the diversity value did not increase, even a slight decrease could be observed. Relying upon these findings we came to the conclusion that as an effect of climate change, the number of Lepidoptera and 
consequently their diversity would decrease. This is also supported by the long-range model developed by Drégelyi-Kiss et al. (2010) and Hufnagel et al. (2008).

Acknowledgements. This work was supported by the Bolyai János Research Scholarship of MTA Doctoral Council, „ALÖKI” Applied Ecological Research and Forensic Institute Ltd., and the TÁMOP 4.2.1/B-09/1/KMR-2010-0005 project.

\section{REFERENCES}

[1] Acara, C., Acarb, H., Eroglu, E. (2007): Evaluation of ornamental plant resources to urban biodiversity and cultural changing: A case study of residential landscapes in Trabzon city (Turkey). - Building and Environment 42: 218-229.

[2] Anderson, M.J. (2008): Animal-sediment relationships re-visited: Characterising species' distributions along an environmental gradient using canonical analysis and quantile regression splines. - Journal of Experimental Marine Biology and Ecology 366: 16-27.

[3] Arnan, X., Gracia, M., Comas, L., Retana, J. (2009): Forest management conditioning ground ant community structure and composition in temperate conifer forests in the Pyrenees Mountains. - Forest Ecology and Management 258: 51-59.

[4] Austin, M. (2007): Species distribution models and ecological theory: A critical assessment and some possible new approaches. - Ecological modelling 200: 1-19.

[5] Balog, A., Marko, V., Adam, L. (2008): Rove beetles (Coleoptera: Staphylinidae) collected during the long term ecological research in a Hungarian oak forest. - Journal of Environmental Biology 29: 263-266.

[6] Bartha, S., Virágh, K., Botta-Dukát, Z., Kertész, M., Oborny, B. (2007): A fajösszetétel: textúra és kotextúra. - In: Pásztor, E., Oborny, B. Ökológia, Nemzeti tankönyvkiadó Zrt. Budapest.

[7] Bazzaz, F.A. (1975): Plant species diversity in old-field successional ecosystems is southern Illinois. - Ecology 65: 485-488.

[8] Bogdanova, G., Georgieva, T. (2008): Using error-correcting dependencies for collaborative filtering. - Data \& Knowledge Engineering 66: 402-413.

[9] Cade, B.S., Noon, B.R. (2003): A gentle introduction to quantile regression for ecologists. - Ecology and the Environment 1: 412-420.

[10] Cade, B.S., Noon, B.R., Flather, C.H. (2005): Quantile regression reveals hidden bias and uncertainty in habitat models. - Ecology 86: 786-800.

[11] Caldas, A. (1992): Mortality of Anaea ryphea (Lepidoptera: Nymphalidae) Immatures in Panama. - Journal of Research on the Lepidoptera 31(3-4): 195-204.

[12] Chamaillé-Jammes, S., Fritza, H., Murindagomoc, F. (2007): Detecting climate changes of concern in highly variable environments: Quantile regressions reveal that droughts worsen in Hwange National Park, Zimbabwe. - Journal of Arid Environments 71: 321326.

[13] Chefaoui, R.M., Lobo, J.M. (2008): Assessing the effects of pseudo-absences on predictive distribution model performance. - Ecological Modelling 210: 478-486.

[14] Cottrell A., Lucchetti R. (2009): Gnu Regression, Econometrics and Time-series Library. http://gretl.sourceforge.net/.

[15] Drégelyi-Kiss, Á., Gimesi, L., Hufnagel, L. (2010): Examination the interaction between the composition of a theoretical ecosystem and the increase in the atmospherical $\mathrm{CO}_{2}$ level. (Bírálat alatt)

[16] Ferenczy, A. (2008): Napi meteorológiai jelentések Excelben. http://www.kutdiak.kee.hu/meteo/.

[17] Ferenczy, A., Varga, R.D., Bíró, I., Kovács, A., Petrányi, G., Hirka, A., Szabóky, Cs., Isépy, I., Priszter, Sz., Türei, D., Gimesi, L., Hufnagel, L. (2010): Fenológiai jelenségek 
és meterorológiai indikátorok kapcsolatának összehasonlító elemzése rovar és növény adatsorok alapján. - LII. Georgikon napok, Nemzetközi tudományos konferencia, Keszthely.

[18] Fisher, R.A., Corbet, A.S., Williams, C.B. (1943): The relation between the number of species and the number of individuals in a random sample of animal population. - Journal of Animal Ecology 12: 42-58.

[19] Gimesi, L., Hufnagel, L. (2010): The possibilities of biodiversity monitoring based on Hungarian light trap networks. - Applied Ecology And Environmental Research 8(3): 223-239.

[20] Helmus, M.R., Bland, T.J., Williams, C.K., Ives, A.R. (2007): Phylogenetic Measures of Biodiversity. - The American Naturalist march 169(3): 68-83.

[21] Hufnagel, L., Sipkay, Cs., Drégely-Kis, Á., Farkas, E., Türei, D., Gergócs, V., Petrányi, G., Baksa, A., Gimesi, L., Eppich, B., Dede, L., Horváth, L. (2008): Klímaváltozás, biodiverzitás és közösségökológiai folyamatok kölcsönhatásai. - In: Harnos, Zs., Csete, L. (szerk): Klímaváltozás: környezet - kockázat - társadalom. Szaktudás Kiadó Ház, Budapest, 229-266.

[22] Izsák, J., Szeidl, L. (2009): Fajabundancia-eloszlási modellek. - Pars Kft. Nagykovácsi.

[23] Jermy, T. (1961): Kártevő rovarok rajzásának vizsgálata fénycsapdával. - A Növényvédelem Időszerü Kérdései 2: 53-61.

[24] Juhász-Nagy, P. (1993): Az eltűnő sokféleség. - Scientia, Budapest.

[25] Kádár, F., Erdélyi, Cs. (1991): Relationships between the air temperatures and the catches of ground beetles (Coleoptera, Carabidae) in a light trap. - Proceedings of the ECE/XIII. SIEEC. Gödöllő, 296-503.

[26] Kevan, P.G. (1999): Pollinators as bioindicators of the state of the environment: species, activity and diversity. - Agriculture, Ecosystems and Environment 74: 373-393.

[27] Kimura, G., Inoue, E., Hirabayashi, K (2008): Seasonal abundance of adult caddisfly (Trichoptera) in the middle reaches of the Shinano River in Central Japan. - 6th International Conference on Urban Pests, Budapest.

[28] Koenker, R., Hallock, K. (2001): Quantile regression. - Journal of Economic Perspectives 15: 143-156.

[29] Kovács, Sz., Csörgő, T., Harnos, A., Nagy, K. (2009): A kerti poszáta (Sylvia borin) vonulási fenológiájának változása Ócsán az elmúlt 24 év során. - Természetvédelmi Közlemények (közlésre elfogadva).

[30] Magurran, A.E. (1988): Ecological Diversity and its Measurement. - Chapman and Hall, London.

[31] Moon, Y., Kim, J. (2007): Efficient moving average transform-based subsequence matching algorithms in time-series databases. - Information Sciences 177: 5415-5431.

[32] National Meteorological Service (2008): Éghajlati adatsorok 1901-2000. http://www.met.hu/.

[33] Nowinszky, L. (1977): Időjárási tényezők rovarokra gyakorolt hatásának elemzése hidrotermikus számok alkalmazásával. - Növényvédelem 13(12): 538-543.

[34] Nowinszky, L. (2003a): A fénycsapdázás kezdete és jelenlegi helyzete. - In: Nowinszky, L. (ed.) (2003): A fénycsapdázás Kézikönyve. Savaria University Press, Szombathely.

[35] Nowinszky, L. (2003b): A fénycsapdás gyüjtési adatok feldolgozási módszerei. - In: Nowinszky, L. (ed.) (2003): A fénycsapdázás Kézikönyve. Savaria Univ. Press, Szombathely.

[36] Nowinszky, L., Ekk, I., Puskás J. (2003): Időjárási elemek. - In: Nowinszky, L. (ed.) (2003): A fénycsapdázás Kézikönyve. Savaria University Press, Szombathely.

[37] Parmesan, C., Yohe, G. (2003): A globally coherent fingerprint of climate change impacts across natural systems. - Nature 421: 37-42.

[38] Persson, B. (1976): Influence of weather and nocturnal illumination on the activity and abundance of population of Noctuids (Lepidoptera) in south coastal Queensland. Bulletin of Entomological Research 66: 33-63. 
[39] Pyle, D. (1999): Data Preparation for Data Mining. - Morgan Kaufmann, San Francisco.

[40] Rácz, V., Bernáth, I. (1993): Dominance conditions and population dynamics of Lygus (Het., Miridae) species in Hungarian maize stands (1976-1985), as functions of climatic conditions. - Journal of Applied Entomology 115: 511-518.

[41] Schmera, D. (2002): Seasonal change of light trap-collected caddisfly (Insecta: Trichoptera) assemblages in the Börzsöny Mountains, northern Hungary. - Proceedings of the 10th International Symposium on Trichoptera / Nova Supplementa Entomologica 15: 559-564.

[42] Skalskia, T., Pośpiech N. (2006): Beetles community structures under different reclamation practices. - European Journal of Soil Biology 42: 316-320.

[43] Suzuki, W., Osumi, K., Masaki T., Takahashi, K., Daimaru H., Hoshizaki, K. (2002): Disturbance regimes and community structures of a riparian and an adjacent terrace stand in the Kanumazawa Riparian Research Forest, northern Japan. - Forest Ecology and Management 157: 285-301.

[44] Szabó, S., Árnyas, E., Tóthmérész, B., Varga, Z. (2007): Long-term light trap study on the macro-moth (Lepidoptera: Macroheterocera) fauna of the Aggtelek National Park. Acta Zoologica Academiae Scientiarum Hungaricae 53(3): 257-269.

[45] Szenteleki, K. (2007): A Környezet - Kockázat - Társadalom (KLIMAKKT) Klimakutatás adatbázis kezelö rendszerei. - Klíma-21 Füzetek 51: 89-115.

[46] Szenteleki, K., Ladányi, M., Szabó, E., Horváth, L., Hufnagel, L., Révész, A. (2007): The climate research database manegement software. - EFITA Conference, Caledonian University Glasgow.

[47] Szentkirályi, F. (2002): Fifty-year-long insect survey in Hungary: T. Jermy's constributions to light trapping. - Acta Zoologica Academiae Scientiarum Hungaricae 48(1): 85-105.

[48] Szontagh, P. (1975): A fénycsapda hálózat szerepe az erdészeti kártevők prognózisában. - Növényvédelem 11: 54-57.

[49] Taylor, L.R. (1963): Analysis of the effect of temperature on insects in flight. - Journal of Animal Ecology 32: 99-117

[50] Tobin, P.C., Nagarkatt I.S., Loeb, G., Saunders, M.C. (2008): Historical and projected interactions between climate change and insect voltinism in a multivoltine species. Global Change Biology 14: 951-957.

[51] Virtanen, T., Neuvonen, S. (1999): Climate change and macrolepidopteran biodiversity in Finland. - Chemosphere: Global Change Science 1: 439-448

[52] Williams, C.B. (1935): The times if activity of certain nocturnal insect, chiefly lepidoptera, as indicated by a light trap. - Trans. Roy.Soc. London, 83: 523-556.

[53] Williams, C.B. (1940): An analysis of four years captures of insects in a light trap. Part II. The effect of weather conditions on insect activity; and the estimation and forecasting of changes in the insect population. - Royal Entomological Society London 90(8): 227-306.

[54] Williams, C.B. (1962): Studies on black flies (Diptera: Simuliidae) taken in a light trap in Scotland. III. The relation of night activity and abundance to weather conditions. Transactions of the Royal Entomological Society of London 114(1): 28-47.

[55] Williams, D.W., Liebhold, A.M. (2002): Climate change and the outbreak ranges of two North American Bark beetles. - Agricultural and Forest Entomology 4: 87-99.

[56] Wolda, H., O'brien, C.W., Stockwell, H.P. (1998): Weevil Diversity and Seasonally in Tropical Panama as Deduced from Light trap Catches (Coleoptera: Curculionoidea). Smithsonian Institution Press, Washington, D.C. 